\title{
Influences of Marketing Mix Elements on Ecotourism Clientele - Jimma Zone, Southwest Ethiopia
}

\author{
Shimekit Kelkay Eshete ${ }^{1 *}$, Derara Ketma Teressa², Wubshet Kassa Wubie ${ }^{1}$, Sukarn Sharma ${ }^{1}$ \\ ${ }^{1}$ Department of Hospitality and Tourism Management, Jimma University, Ethiopia \\ ${ }^{2}$ Department of Tourism Management, Arbaminch University, Ethiopia
}

\begin{abstract}
This study assessed the influence of marketing mix elements (7 Ps i.e. Product, Price, Place, Promotion, People, Process and Physical Evidence) on ecotourism clientele in Jimma Zone, South West Ethiopia. According to the data received from the Jimma Zone Cultural and Tourism office, a total of 23 woredas are under the Jimma zone. From these, the researchers selected six, which are endowed with ecotourism resources. The target population for this study was all Government staff working here and the research was conducted in July 2019. The study adopted a census or total enumeration method because the total population of the study was small. The instrument for the study consists of a structured questionnaire. Multiple regression analysis and descriptive statistics were used as a method for data analysis. The findings of the study revealed that physical evidence made the highest contribution followed by product development, promotion, process, people and place on ecotourism clientele. This implies marketing mix elements enhances ecotourism development and the key stakeholders should consider the proper implementation of such marketing mix elements for sustainable development and promotion of ecotourism in Jimma zone.
\end{abstract}

Keywords: Marketing Mix, Ecotourism Development, Ecotourism Destinations, Consumer Behaviour, Multiple Regression.

\section{INTRODUCTION}

Tourism is increasingly becoming an important economic sector in many developing countries [1]. However, for the successful development of tourism, the Society, State, and Private companies must work in collaboration and cooperation with each other [2]. This industry is one of the major sources of foreign exchange, earnings, and the most viable and sustainable economic development option. It contributes $11 \%$ of the world GNP [3]. The governments have always tried to strategize tourism in such a way so that the less fortunate group of people can benefit from the trickledown effect [4].

In this context, Ecotourism emerged as a sustainable form of tourism. Ecotourism can help in cultural preservation, environmental conservation, and increase community income at a tourist attraction [5]. Ecotourism continues to generate revenue for the third world countries, like, African countries. For example, in Ghana, the tourism sector stands fourth behind gold, cocoa, and foreign remittances and earned revenue that is equivalent to $6.2 \%$ of Gross Domestic Product [6]. In East Africa, the ecotourism market is the niche market, especially in Tanzania, Kenya, and Ethiopia. It was because

\footnotetext{
* Correspondence address:

Shimekit Kelkay Eshete

Email : skelkay@gmail.com

Address : Dept. of Hospitality and Tourism Management, Jimma University, Ethiopia
}

these countries were endowed with natural and cultural products and resources that support ecotourism development [7].

With abundant ecotourism resources in Ethiopia and on paper having $15 \%$ of its land protected [8], most of these protected areas do not have legal status and are practically inadequately protected [9]. As different writers state that Ethiopia has a long way to go to benefit from tourism. For instance, according to a report published by the World Tourism Organization in 2002 [10], the share of Ethiopia from the tourism sector was just less than minuscule. A total of 156,327 international tourists visited Ethiopia and accounted for 77 million USD in revenue, with a $5 \%$ growth rate compared to 2001. In 2005, international tourists visiting Ethiopia showed considerable growth, although not up to expectations [10].

Even after Ethiopia was endowed with natural and cultural products and resources, ecotourism development lacks either new products or is unable to attract a new market as expected. One of the major reasons for this problem is the inability to develop an effective marketing mix.

Different scholars define the marketing mix in different ways. The marketing mix, defined as the elements an organization controls that can be used to satisfy or communicate with customers [11]. The marketing mix is the set of marketing tools that the firm uses to pursue its marketing objectives in the target market [12]. The tools of marketing have been classified into four broad 
groups and have been referred to as 4Ps of marketing; product, price, place, and promotion [13]. The marketing mix has been described as the internal elements or ingredients that make an organization marketing program [14].

However, it is asserted that the four Ps model is unnecessarily restrictive, while an expanded marketing mix is recommended because it should include, people, physical evidence, and processes. Other scholars of services marketing $[15,16]$ also agree that the traditional marketing mix of 4Ps needs to be extended to 7Ps. The marketing mix then translated to become the 7Ps of marketing, where the extended Ps caters for service marketing [17].

It is well known that the characteristics of tourism, specifically ecotourism make it impossible to taste or test the benefits expected before purchase. Even more, it cannot be moved from its location while it is still intangible, means that customers cannot hold, touch, taste the product until it is purchased. Therefore, it makes the proper application of marketing mix elements necessary to link the potential ecotourism product with the potential tourism market and to the rest of the world. This study focuses on investigating the influence of the seven components of the marketing mix, as being product development, price, place, promotion, people, physical evidence, and process upon ecotourism clientele in Jimma Zone.

\section{Hypotheses}

For this research the following hypotheses were formulated and tested at 0.05 significance levels.

$\mathbf{H}_{01}$ : There is no significant effect of product planning and development on ecotourism clientele in Jimma Zone.

$\mathbf{H}_{02}$ : There is no significant relationship between price and ecotourism clientele in Jimma Zone.

$\mathbf{H}_{03}$ : There is no significant effect of promotion on ecotourism clientele in Jimma Zone.

$\mathbf{H}_{04}$ : There is no significant effect between distribution strategy and ecotourism clientele in Jimma Zone.

$\mathrm{H}_{05}$ : There is no significant relationship between people (personnel) and ecotourism clientele in Jimma Zone.

$H_{06}$ : There is no significant effect between Process and ecotourism clientele in Jimma Zone.

$\mathbf{H}_{07}$ : There is no significant relationship between physical evidence and ecotourism clientele in Jimma Zone.

\section{MATERIAL AND METHOD}

The population of this study consisted of the Government officials in selected tourism destinations in the Jimma zone. As per the data received from the Jimma Zone Cultural and Tourism office, the total woredas under the zone is 23 . From a total of 23 woredas, the researchers purposively selected six areas which are endowed with ecotourism resources. These areas were selected because they offer a wide range of potential resources for ecotourism.

The study adopted a census or total enumeration method because the total population of the study is small. Therefore, all the members of the population were involved and no part was selected for another. All the 120 staff comprised of Govt. officials (administrators and experts) at the selected tourism locations were given questionnaires and out of 120 distributed questionnaires 110 (91.6\%) were returned. The research was conducted in July 2019.

\section{Data Collection}

The data was collected by administering a structured interview and self-administered structured questionnaire. The instrument for the study consists of a structured questionnaire in which the dependent and independent variables were measured on a five-point Likert Scale. The questionnaire items on the variables were adapted from previous studies based on the similarities with the present study. A pilot survey was also conducted on ten random respondents out of the sample size to test the reliability of each item of the instrument.

\section{Data Analysis}

Method of analysis involved descriptive and inferential statistics. The descriptive statistics have shown the variation in responses and opinions using mean and standard deviations. Inferential analysis was done using statistical tools. This tool includes the regression analysis with the aid of SPSS that tested the effect of the predictor variables on the dependent variables.

\section{RESULT AND DISCUSSION}

\section{Product planning and development}

According to the respondents, the aggregate mean score and standard deviation of each of the variables of marketing mix elements were shown in Table 1. Most respondents stated negatively regarding ecotourism product planning and development in the Jimma zone. It seems that the reasons for such responses are the lack of fundamental infrastructure at the destination, absence of technical know-how regarding tourism development, and unavailability of trained staff.

\section{Price}

The prices are a bit on the higher side, and not enough discounts were provided to make the destination attractive, though food has been 
rated as inexpensive (Table 1 ). It can be due to the eagerness of service providers to earn more money in less amount of time. On top of that, as a lot of tourists don't come to these places, it may also because the providers want to extract as much money as possible from whosoever is visiting their destination. It is not uncommon to see as private enterprises many times are shortsighted and look only for immediate profits rather than long term gains.

Place

The means of reserving accommodation and making payments were not well provided (Table 3). It was attributed to the lack of online booking facilities on the website. As far as the tourists traveling to the destination is concerned, there are only two flights to Jimma in a day from the Capital Addis Ababa. Apart from that, many tourists may also find it more interesting to travel by road to see the countryside, though the condition of the road is not good.

\section{Promotion}

The promotion efforts of the service providers are not good enough to attract the customers (Table 4). It may be because the service providers were not well versed with the tools and techniques of promotion and don't have good IT skills.

Table 1. Descriptive statistics of product planning and development

\begin{tabular}{|c|c|c|c|c|}
\hline Variables & Min & Max & Mean & Std. Dev. \\
\hline 1. Brand identity is being represented by the names of Ecotourism destinations & 1.00 & 4.00 & 1.99 & 0.82 \\
\hline 2. Customers (tourists) feel satisfied by the products offered at ecotourism destination & 1.00 & 4.00 & 2.12 & 0.85 \\
\hline 3. Attractions at your destination and environment are encouraging & 1.00 & 4.00 & 2.20 & 1.02 \\
\hline 4. Customers are attracted by the services and facilities at your destination & 1.00 & 4.00 & 1.84 & 0.83 \\
\hline 5. Perception of your location is positive, and it encourages people to visit your destination & 1.00 & 4.00 & 1.98 & 0.81 \\
\hline 6. Your souvenirs, gift, etc are patronized by customers & 1.00 & 5.00 & 2.14 & 0.91 \\
\hline
\end{tabular}

Source: Field Survey, 2019, N=110.

Table 2. Descriptive statistics of price

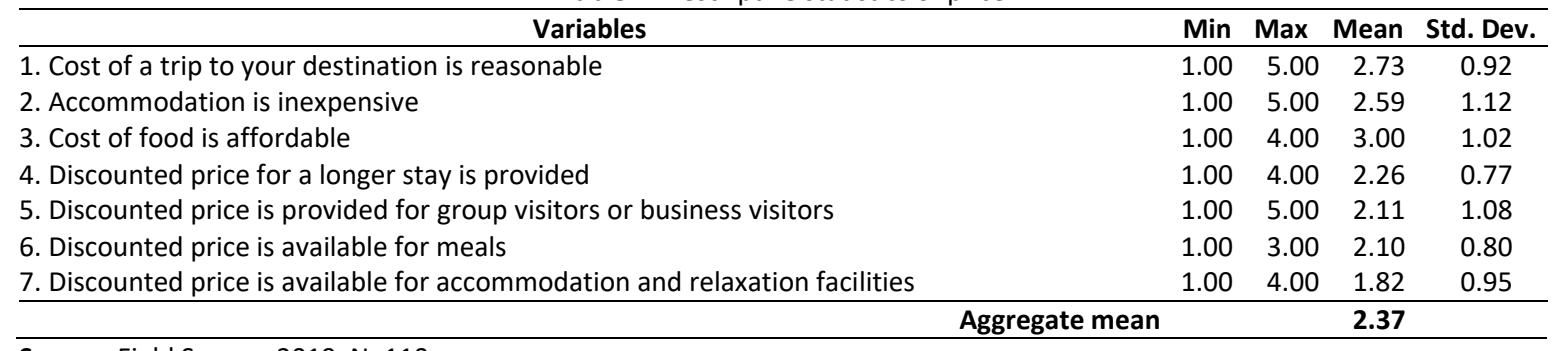

Source: Field Survey, 2019, N=110.

Table 3. Descriptive statistics of place

Variables Min Max Mean Std. Dev.

\begin{tabular}{|c|c|c|c|c|}
\hline 1. Means of confirming reserved accommodation, make \& confirm payment are well provided & 1.00 & 3.00 & 1.89 & 0.74 \\
\hline 2. Tourists come by airlines & 1.00 & 3.00 & 1.75 & 0.71 \\
\hline 3. Roads to traveling locations are good & 1.00 & 4.00 & 1.92 & 0.80 \\
\hline
\end{tabular}

Source: Field Survey, 2019, N=110.

Table 4. Descriptive statistics promotion

\begin{tabular}{|c|c|c|c|c|}
\hline Variables & Min & Max & Mean & Std. Dev. \\
\hline 1. Website provides enough information about your ecotourism products and services & 1.00 & 4.00 & 1.88 & 0.98 \\
\hline 2. Trade shows adequately promote your tourism destinations & 1.00 & 4.00 & 1.99 & 0.96 \\
\hline 3. Marketers /Ambassadors are employed to inform people about your tourism services & 1.00 & 4.00 & 2.14 & 1.07 \\
\hline 5. The name of your ecotourism location is sufficient to tangibilize your services & 1.00 & 4.00 & 2.04 & 0.95 \\
\hline 6. The logo used for ecotourism destination is enough to attract customers & 1.00 & 4.00 & 1.95 & 0.94 \\
\hline 9.Newspapers provide tourism information regarding your destinations & 1.00 & 4.00 & 1.70 & 0.94 \\
\hline \multicolumn{3}{|c|}{ Aggregate mean } & 1.95 & \\
\hline
\end{tabular}

Source: Field Survey, 2019, N=110. 


\section{People}

The results displayed in Table 5 indicate the paucity of education and training to the staff of the service providers. Though the number of hospitality and tourism programs in the country has been continuously increasing, still not many Universities offer courses at the post-graduate level, which can help people to be trained better for higher positions. Other than this, not many institutes offer short-term training in various departments of the hotel. The providers also employ people with less education to save money.

\section{Process}

The results in Table 6 indicate that the staff was deprived of adequate training. It also appears that the local community neither knows the benefits of tourism nor have any vested interests in tourism projects. It may be due to low levels of education in the community.

Table 5. Descriptive statistics of people

\begin{tabular}{|c|c|c|c|c|}
\hline Variables & Min. & Max. & Mean & $\begin{array}{l}\text { Std. } \\
\text { Dev. }\end{array}$ \\
\hline 1. Staff is well trained & 1.00 & 5.00 & 2.82 & 1.06 \\
\hline 2. Client friendliness and treatment is emphasized during the training and selection of personnel & 1.00 & 5.00 & 3.01 & 0.99 \\
\hline 3. Staff appearance positively impacts on the satisfaction of our customers & 1.00 & 5.00 & 3.25 & 0.91 \\
\hline 4. Our staff are equipped with flexible skills that encourage patronage & 1.00 & 5.00 & 3.07 & 0.87 \\
\hline 5. Staff involved in the tourist visit experience offer good service by their attitude towards tourists & 1.00 & 5.00 & 3.01 & 0.98 \\
\hline $\begin{array}{ll} & \text { Aggregate mean }\end{array}$ & & & 3.03 & \\
\hline
\end{tabular}

Source: Field Survey, 2019, N=110.

Table 6. Descriptive statistics of process

\begin{tabular}{|c|c|c|c|c|}
\hline Variables & Min. & Max. & Mean & Std. Dev. \\
\hline 1. Procedure of service delivery is appreciated by the tourists & 1.00 & 4.00 & 2.19 & 0.79 \\
\hline 2. Tourists are given a warm welcome & 1.00 & 4.00 & 2.71 & 0.68 \\
\hline 4. Tourists are provided with good food & 1.00 & 4.00 & 2.64 & 0.73 \\
\hline 5. Tourists are quickly linked with their hotels & 1.00 & 4.00 & 2.23 & 0.78 \\
\hline 6. There are good options for the entertainment of tourists & 1.00 & 4.00 & 2.73 & 0.76 \\
\hline 8. Life is very easy for tourists at your center & 1.00 & 5.00 & 2.52 & 0.92 \\
\hline \multicolumn{3}{|c|}{ Aggregate mean } & 2.53 & \\
\hline
\end{tabular}

Source: Field Survey, 2019, N=110.

Table 7. Descriptive statistics of physical evidence

\begin{tabular}{|c|c|c|c|c|}
\hline Variables & Min & Max & Mean & Std. Dev. \\
\hline 1. Photographs showing all aspects of ecotourism destination are available & 1.00 & 5.00 & 3.55 & 1.17 \\
\hline 2. Photographs of past tourists are displayed as testimonials & 1.00 & 5.00 & 2.65 & 1.12 \\
\hline $\begin{array}{l}\text { 3. Gift items, artwork, and souvenir are displayed for sale to remove the intangible nature } \\
\text { of ecotourism services }\end{array}$ & 1.00 & 5.00 & 2.38 & 1.08 \\
\hline \multicolumn{3}{|l|}{ Aggregate mean } & 2.85 & \\
\hline
\end{tabular}

Source: Field Survey, 2019, N=110.

Table 8. Descriptive statistics of ecotourism clientele

\begin{tabular}{|c|c|c|c|c|}
\hline Variables & Min & Max & Mean & Std. Dev. \\
\hline 1. Our hotels are more popular than others in Southwest, Jimma zone & 1.00 & 4.00 & 1.82 & 0.76 \\
\hline 2. Our hotels are making good profits from places for children and others to play & 1.00 & 3.00 & 1.57 & 0.65 \\
\hline $\begin{array}{l}\text { 4. Our hotels' dynamic actions, quality of accommodation, pricing, and service quality } \\
\text { stimulate constant visits by current and potential tourists. }\end{array}$ & 1.00 & 3.00 & 2.11 & 0.79 \\
\hline $\begin{array}{l}\text { 6. The comfort, security, amenities, shelter, ambiance, vistas, recreational facilities, } \\
\text { convenience, food, and beverage facilities of our resorts led to consistent patronage. }\end{array}$ & 1.00 & 3.00 & 2.07 & 0.65 \\
\hline 7. The average income generated in our resorts annually is very high & 1.00 & 3.00 & 1.99 & 0.71 \\
\hline $\begin{array}{l}\text { 8. Overall, tourists' patronage is high because our resorts provide beautiful landscapes, } \\
\text { natural resources, and scenic environment to tourists. }\end{array}$ & 1.00 & 3.00 & 2.03 & 0.75 \\
\hline
\end{tabular}

Source: Field Survey, 2019, N=110 


\section{Physical Evidence}

As shown from Table 7, the respondents felt that even when photographs of ecotourism destinations are available, there are not many photographs of past tourists displayed as testimonials. Also, not enough souvenirs were displayed for sale to the tourists It looks like that tourist was either having privacy issues because they are not allowing the service providers to display their pictures as testimonials or the service providers do not have the required knowledge of tools and techniques of promotion. Apart from leaving the main city of Jimma, the less availability of souvenirs may be due to the limited number of artisans.

\section{Ecotourism Clientele}

Table 8 illustrates that the majority of the respondents did not agree that ecotourism clientele consistently is more or the hotels/ resorts can make more profits as compared to other tourist attractions in the studied area. It may be due to the inability of the suppliers to create the uniqueness of their tourism product, along with the dearth infrastructure and appropriate training of the staff.

\section{Regression Analysis}

Regression analysis was used to assess the relationship between one dependent variable and several independent variables. The researchers have presented a regression model in Table 9. The independent variables were product development, price, place, promotion, people, process, and physical evidence. And the dependent variable, which is affected by the independent variable, is ecotourism clientele.
The first step of the multiple regression analysis is testing multicollinearity. Multicollinearity inflates the variances of the parameter estimates. Hence, this may lead to a lack of statistical significance of individual predictor variables even though the overall model may be significant. Other stated Collinearity Statistics gives two valuesTolerance and VIF (Variance Inflation Factor). As one can see, Tolerance is just the inverse of VIF. A value of VIF higher than five (or Tolerance less than 0.2) indicates the presence of multicollinearity. In social sciences research, a VIF value as high as 10.0 is considered to be acceptable [18].

So as researchers try to illustrate data on the correlation's matrix, there is no apparent multicollinearity existing among the variables. They rather have moderate collinearity. Also, as the researcher examined collinearity statistics of tolerance and variance inflations factors (VIF) value on the coefficient Table 9, is close to 1 or greater than 0.2 and no more than 5 . This finding indicates that there is no presence of multicollinearity.

The next part of the multiple regression analysis that is important is the Model summary Table 10 and the ANOVA Table 11. The Model Summary Table 10 includes the R Square value, which serves as the proportions of the variation in the dependent variable (ecotourism clientele) explained by the variation in the independent variable. In other words, this means that the $\mathrm{R}$ Square depicts how good the regression model is at explaining the variance in ecotourism clientele.

Table 9. Regression model for coefficients

\begin{tabular}{|c|c|c|c|c|c|c|c|}
\hline \multirow[t]{2}{*}{ Model } & \multicolumn{2}{|c|}{$\begin{array}{c}\text { Unstandardized } \\
\text { Coefficients }\end{array}$} & \multirow{2}{*}{$\begin{array}{c}\begin{array}{c}\text { Standardized } \\
\text { Coefficients }\end{array} \\
\text { Beta } \\
\end{array}$} & \multirow[t]{2}{*}{$\mathbf{t}$} & \multirow[t]{2}{*}{ Sig. } & \multicolumn{2}{|c|}{ Collinearity Statistics } \\
\hline & B & Std. Error & & & & Tolerance & VIF \\
\hline (Constant) & -.949 & .894 & & -1.062 & .291 & & \\
\hline Product development & .183 & .038 & .252 & 4.765 & .000 & .569 & 1.756 \\
\hline Price & -.007 & .022 & -.014 & -.348 & .729 & .968 & 1.034 \\
\hline Place & .076 & .034 & .108 & 2.207 & .030 & .671 & 1.490 \\
\hline People & .138 & .035 & .183 & 3.984 & .000 & .756 & 1.323 \\
\hline Process & .187 & .045 & .220 & 4.122 & .000 & .559 & 1.788 \\
\hline Physical Evidence & .254 & .042 & .297 & 6.015 & .000 & .654 & 1.529 \\
\hline
\end{tabular}

a. Dependent Variable: Ecotourism clientele

The outcomes are as follows:

Estimated Ecotourism clientele $(\mathrm{Y})=-0.949+0.252^{*}$ Product $-0.014 *$ Price $+0.108 *$ Place $+0.244^{*}$ Promotion + $0.183 *$ People $+0.220^{*}$ Process $+0.297 *$ Physical Evidence $+\mathrm{e}$ - (Indicates random error)

Table 10. Model summary of R square

\begin{tabular}{lcccc}
\hline Model & R & R Square & Adjusted R Square & $\begin{array}{l}\text { Std. Error of the } \\
\text { Estimate }\end{array}$ \\
\hline 1 & $.915^{\mathrm{a}}$ & .838 & .826 & 1.14400 \\
\hline a. Predictors: (Constant), Physical Evidence, Price, People, Place, Promotion, product development, Process
\end{tabular}


Table 11. Summary of ANOVA

\begin{tabular}{|c|c|c|c|c|c|}
\hline Model & Sum of Squares & df & Mean Square & $\mathbf{F}$ & Sig. \\
\hline Regression & 688.009 & 7 & 98.287 & 75.101 & $.000^{\mathrm{b}}$ \\
\hline 1Residual & 133.491 & 102 & 1.309 & & \\
\hline Total & 821.500 & 109 & & & \\
\hline \multicolumn{6}{|c|}{$\begin{array}{l}\text { a. Dependent Variable: Ecotourism Clientele } \\
\text { b. Predictors: (Constant), Physical Evidence, Price, People, Place, Promotion, product, Process }\end{array}$} \\
\hline
\end{tabular}

Table 12. Test of study hypotheses

\begin{tabular}{|c|c|c|}
\hline Hypotheses & $\begin{array}{l}\text { Coefficient P- } \\
\text { Values }\end{array}$ & Conclusion \\
\hline $\begin{array}{l}\mathbf{H}_{01} \text {. There is no significant effect of product planning and development on ecotourism } \\
\text { clientele. }\end{array}$ & $\mathrm{P}=.000$ & Reject $\mathrm{H}_{0}$ \\
\hline $\mathbf{H}_{\mathbf{0 2} .}$ There is no significant relationship between price and ecotourism clientele. & $P=.729$ & Fail to Reject $\mathrm{H}_{0}$ \\
\hline $\mathbf{H}_{03}$. There is no significant effect of promotion on ecotourism clientele. & $\mathrm{P}=.001$ & Reject $\mathrm{H}_{0}$ \\
\hline $\mathbf{H}_{04 .}$ There is no significant effect between distribution strategy and ecotourism clientele. & $P=.030$ & Reject $\mathrm{H}_{0}$ \\
\hline $\begin{array}{l}\mathbf{H}_{05} \text {. There is no significant relationship between people (personnel) and ecotourism } \\
\text { clientele. }\end{array}$ & $P=.000$ & Reject $\mathrm{H}_{0}$ \\
\hline $\mathbf{H}_{06 .}$ There is no significant effect between Process and ecotourism clientele. & $P=.000$ & Reject $\mathrm{H}_{0}$ \\
\hline $\begin{array}{l}\mathbf{H}_{07} \text {. There is no significant relationship between physical evidence and ecotourism } \\
\text { clientele. }\end{array}$ & $P=.000$ & Reject $\mathrm{H}_{0}$ \\
\hline
\end{tabular}

The value of the $R$ square - which is the proportion of the variation in the dependent variable accounted for by the seven independent variables - was acceptable. The coefficient of determination ( $R$ square) is a measure of how good prediction of the criterion variable that can be selected by knowing the predictor variables. Accordingly, $83.8 \%$ of the variation in the dependent variable was explained by the set of the above independent variables. However, Rsquared measures the proportion of the variation in the dependent variable explained by independent variables, irrespective of how well they are correlated to the dependent variable. This is not a desirable property of a goodness of fit statistic. Conversely, adjusted R - squared provides an adjustment to the $R$ - squared statistic such as an independent variable that has a correlation to dependent variable increases adjusted $\mathrm{R}$ - squared and any variable without a strong correlation will make adjusted R- squared decrease. Therefore, to see the success of the model in the real world adjusted R- squared more is preferable than $\mathrm{R}$ - squared [19]. Accordingly, adjusted R-squared, the variation is explained by the regression of dependent variable on the combined effect of all the predictor variables is $82.6 \%$. Hence, generally speaking, the independent variables can predict the dependent variable by $82.6 \%$.

This is a good finding, but in order to find out if it is significant one must study the ANOVA table. The ANOVA table 11 shows that the finding is significant because the $p$-value is less than significance level $0.1 \%$. This indicates that the overall model was reasonable fit and there was a statistically significant association between marketing mix and ecotourism clientele.

\section{Summary}

After the analysis, hypotheses of this study were tested. Table 12 presents the summary of findings of the hypotheses.

The ecotourism clientele of the studied area has a significant effect due to product planning and development. According to the result of the first research hypothesis, it can be stated that the null hypothesis has been rejected. Many researchers have also suggested previously that different dimensions of product development, such as product quality and product lines/product mix were positively and significantly correlated with the corporate performance of profitability, sales volume, and customer loyalty.

It was further established that a relationship exists between product size, product design and profitability, sales volume, and customer loyalty [20]. Hence, the findings of this research are in line with the findings of other researchers regarding this aspect. In addition, it is also important to note that most of the respondents have also stated negatively regarding ecotourism product planning and development in the Jimma zone. It looks like the provision of infrastructure, funding of the tourism sector, and training to the local people can be the way forward.

Whereas the variable price is concerned the researchers were not able to find enough 
evidence to reject the null hypothesis. It may be possible that the clients are looking for better ecotourism products and facilities, even if they have to pay a higher price. However, attention should also be paid that at the same time, the respondents have also stated that the prices are a bit on the higher side, and not enough discounts provided to make the destination attractive. Keeping the above in view, it can be stated that more research needs to be done regarding this aspect.

Considering the effect of place or accessibility on ecotourism clientele, the finding depicted that place has a significant effect on ecotourism clientele in the selected tourism destination. It can be stated that according to the result of the third research hypothesis, the null hypothesis has been rejected. This finding is consistent with the other researchers according to whom the place must be easily accessible, possess an attractive physical appearance, have a pleasant, convenient, functional environment, and have safe and pleasant surroundings [20]. Whereas this factor is concerned, it has also not been rated positively. Maintenance of roads, as well as provision of a greater number of flights, can be one of the aspects to be looked upon by the Government. In addition, better distribution strategies, such as online booking facilities on the website, can also be considered.

The fourth hypothesis ascertained whether promotion has any significant influence on ecotourism development in Jimma Zone. The findings revealed that promotion has a significant influence on Ecotourism clientele in the studied area. Other researchers also explained promotion refers to all activities by the company that communicate the merits of the product and persuade target customers to buy it. Different promotional strategies, such as advertising, personal selling and public relations, can be used to ensure that the customer buys the product [21]. However, in the case of the Jimma Zone, this attribute has also been rated negatively. Training of tools and techniques of promotion, as well as digital marketing, may help to overcome this limitation.

The finding of the fifth hypothesis depicted that the attribute people have a significant influence on the development of ecotourism clientele in the studied area. It means that tourism destinations with qualified and experienced personnel would have a larger number of clients than those with inexperienced personnel. As other researchers have stated, people include all human actors who play a part in the delivery of services and thus affect the perception of buyers. Given the inseparability nature of tourism products, many stakeholders were involved in the buying and selling, namely the customer, other customers, and the firm's personnel in the service environment [22].

People generally cannot be separated from the total service. They enhance the tangibility of the product-service combination [23]. Additionally, tourism is labor- intensive, and the tourism experience is dependent on a tourist's interaction with local communities and welltrained personnel working in those destinations [24]. The attribute of people has been rated as neutral by the respondents. Keeping in mind that any destination with experienced staff will be patronized more by the clients. Thus, training for the people working in the tourism industry can be undertaken.

The statistical results for the sixth hypothesis revealed that the effect of the process on ecotourism clientele at selected ecotourism destination has a significant effect. This finding is supported by other researches, in which it has been stated that in services marketing, how the service delivered is paramount. For example, service system performance determines the length of customer waiting time [25]. The process element can be a major way of differentiating a service provider from the competition [25]. The rating for the attribute process is also not satisfactory. Proper training of the staff and tourism awareness programs in the community can help to correct the situation.

The findings of the study also revealed that physical evidence has a significant influence on ecotourism clientele in the selected ecotourism destinations in the Southwest Oromia region of Jimma zone. There are similar findings in other researches also regarding physical evidence. According to one of the researches, the physical evidence included aspects such as the service provider's building/facilities and staff appearance, while other aspects are personal hygiene and uniforms. in addition, promotional materials and branding strategies are all elements of physical evidence that serve to tangibilize a service offering to a customer.

These physical evidence cues are what potential customers use to evaluate accurately or inaccurately things like service quality [25]. This attribute has also not been rated very well by the respondents. The potential clients may feel attracted to the destination if they can see some 
pictures of other people enjoying at the destination. It may help to evoke a feeling within the potential clients to enjoy the destination the same way as other people have enjoyed. It may also help if they can see some souvenirs etc. from the place. These things may also help to provide some tangibility to the highly intangible nature of tourism.

\section{CONCLUSION}

This study investigated the influence of marketing mix elements on ecotourism clientele in Jimma Zone, Southwest Ethiopia. From the literature review, the researchers identified seven independent variables (7ps of the marketing mix) and one dependent variable of ecotourism clientele. The main finding of this study was that $6 \mathrm{ps}$ out of $7 \mathrm{ps}$ of marketing elements significantly influenced the ecotourism clientele, and these elements are not doing well in the Jimma zone. The standardized coefficient (Beta weights, $\beta$ ) of the variables indicated that Physical Evidence made the highest contribution $(\beta=.297, \quad p<.01) \quad$ followed by Product Development $\quad(\beta=.252, \quad p<.01)$; Promotion $(\beta=.244, p<.01)$; Process $(\beta=.220, p<.01)$; People $(\beta=.183, p<.01)$; and Place $(\beta=.108, p<.05)$ in influencing the ecotourism clientele.

In tourism, it is not only an attractive environment that is important, but an effective application of all the marketing mix elements also plays a vital role. Provision of essential infrastructure, appealing product, a good website, easy accessibility, ambient conditions, layout and symbols, decor, friendly staff along with well-trained people at the tourism office can help to create a positive image in the minds of the potential customers. It can also subsequently help in giving a mesmerizing experience to the tourists. It is quite clear from this study that the destination was unable to take the benefits of the elements of the marketing mix. The destinations may gain a competitive advantage by first finding their USP (Unique Selling proposition) and thereafter, leveraging on it. In the future, in-depth studies regarding the effects of marketing mix elements may also be conducted at other ecotourism destinations.

\section{REFERENCES}

[1] UNCTAD. 2007. FDI in tourism: the development dimension, UNCTAD current studies on FDI and development No. 4, New York and Geneva, United Nations.

[2] Mindarti, I. L. and F. M. Lazuardi. 2019. Three pillars partnership in the tourism destinations management in order to actualize good tourism governance (study on a rafting tour in Probolinggo Regency). Journal of Indonesian Tourism and Development Studies 7(3), 140-145.

[3] UNWTO. 2005. Declaration: Harnessing Tourism for the Millennium Development Goals. New York, $13^{\text {th }}$ September 2005.

[4] Puspitarini, C. R. and I. Anggraini. 2019. Trickle-down economics' Arthur Lewis Fails: an economic development study of Mount Bromo in Ngadisari Village, Sukapura District, Probolinggo Regency, East Java, Journal of Indonesian Tourism and Development Studies 7(3), 131-139.

[5] Henri, H., L. Hakim, and J. Batoro. 2017. Ecotourism development strategy of Pelawan Forest in Central Bangka, Bangka Belitung, Journal of Indonesian Tourism and Development Studies 5(3), 145-154.

[6] Ghana Ministry of Tourism. 2010. Community-based ecotourism and poverty alleviation. Final Report. 1-19, 40-43. Accra: GTA.

[7] Nigatu, T. F. 2016. Potentiality assessment for ecotourism development in dida hara conservation site of borena nationalpark, ethiopia. International Journal of Tourism \& Hospitality Reviews, 45-59.

[8] Biodiversity Indicators Development National Task Force. 2010. Ethiopia: overview of selected biodiversity indicators. Addis Ababa.

[9] Ethiopian Institute of Biodiversity. 2014. Conservation, Sustainable Use \& Access and Benefit Sharing. Ethiopian Institute of Biodiversity. Addis Ababa, Ethiopia.

[10] Amenu, B.T. 2017. Review on trends of ecotourism development in Ethiopia. Journal of Tourism, Hospitality and Sports, $1-10$.

[11] Zeithaml, V. A. and M.J. Bitner. 2000. Services marketing-integrating customer focuses across the firm, $2^{\text {nd }}$ Ed. 19-21. Tata McGraw Hill Publication. India.

[12] Kotler, P. 2003. Marketing management $11^{\text {th }}$ Ed. Prentice Hall International Edition.

[13] McCarthy, J. 1964. Basic marketing: a managerial Approach, $2^{\text {nd }}$ Ed. Richard D. IRWIN, INC.

[14] Payne, A. 1993. Relationship marketing: the six markets framework. School of Management Working Papers.

[15] Baron, S. 1995, Marketing: text and cases. The McMillam Press Ltd. Basingstoke, 
Hampshire.

[16] Lovelock, C. 1991, Services marketing. NJ Prentice-Hall. Englewood Cliffs.

[17] Sindiga, D. 2005. Marketing strategies adopted by Kenya Tourist Board to market Kenya as a tourism. Hospitality and tourism.

[18] Gaur, A. S. 2009. Statistical methods for practice and research. SAGE Publications Ltd. California.

[19] Burns, R. and R. Burns. 2008. Cluster analysis. In: Business Research Methods and Statistics Using SPSS. Sage Publications.

[20] Oyebode. 2017. Marketing strategy and tourism patronage in southwest nigeria. Babcock.

[21] Talabi, J. 2015. The role of marketing in hotel industry case (Six successful hotel units in Abuja and Jakobstad). Thesis Degree Programme in Tourism Centria University Of Applied Sciences. Finland.

[22] Zeithaml, V., M. J. Bitner, and D. D. Gremler, 2006. Services marketing, integrating customer focus across the firm. McGrawHill. New York.

[23] Reid, R. and D. Bojanic. 2010. Hospitality marketing management, $5^{\text {th }} \mathrm{Ed}$. John Wiley and Sons, inc. Hoboken, New Jersey.

[24] Kamau, F., F. K. Waweru, P. Lewa, and A. J. Misiko. 2015. The effects of the marketing mix on choice of tourist accommodation by domestic tourists in Kenya. International Journal of Novel Research in Marketing Management and Economics 2(2), 25-34.

[25] Asiegbu, I. F., P. Igwe, and N. Akekue-Alex. 2012. Physical evidence and marketing performance of commercial airlines in Nigeria. American International Journal of Contemporary Research 2(12), 136-149. 